\title{
Salaf Pesantren in Digital Era: Continuity of Classical and Modern Learning Systems at Pondok Pesantren Langitan, Widang, Tuban
}

\author{
N Azizah ${ }^{1}$ \\ Universitas Wahid Hasyim, Semarang, Indonesia ${ }^{1}$ \\ \{qnaazizatyi@yahoo.co.id ${ }^{1}$ \}
}

\begin{abstract}
This research aims to study the continuity of the classical and modern education system at Pondok Pesantren Langitan Widang Tuban. This research is qualitative field research using a case study. The data is collected with observation, interviews, and documentation. The subjects of this research are Kiai, bu nyai, ustaż, santri, and society. This research shows that Islamic Boarding Schools in Tuban Widang still maintain the tradition by using bandongan, wetonan, sorogan learning system. For certain learning Langitan Islamic Boarding Schools are equipped with TV, LCD and projectors and are connected with Youtube, Facebook, Instagram, and official radio pesantren accessible for the public.
\end{abstract}

Keywords: Salaf Pesantren, Classical Learning, Modern Learning

\section{Introduction}

The development of the digital world is rapidly considerable in the era of the Industrial Revolution 4.0 which resulted in major changes in society. The social scientists called it an era of disruption which has impacts on every sector, such as economic, political, and educational sectors, including pesantren institutions. The inevitability of the digital era demands Islamic education to adapt itself in order to not be left behind other models of education. Islamic education with all its resources is expected to take advantage of the digital era to strengthen its existence as a pioneer of superior and quality education, both in the context of Indonesians and in the global civilization. Digital transformation is necessary for boosting learning systems in Islamic boarding schools.

The learning system of salaf Islamic boarding school known as bandongan, wetonan, and sorogan needs to be developed to fulfill the demands of the present era. Salaf Islamic boarding schools have a big challenge for adjusting the community's needs to maintain their identity. On the one hand, the Islamic boarding school wants to maintain the salaf tradition as an inherent self-identity since the beginning of its existence. But on the other hand, social change requires Islamic boarding schools to adapt and build some of the changes related to the perspective and the followed traditions, as have done by some of salaf Islamic boarding schools. 
Lirboyo Islamic boarding school with its salaf characteristics still maintains the great traditions that exist in the pesantren, such as the classical book learning and classical learning methods. To improve the quality of learning, Lirboyo Islamic Boarding School has used binoculars and scientific calculators as media for learning astronomy and computerization for internet in the boarding school management and communication improving [1]. It indicates that Lirboyo Islamic Boarding School still exists with its salaf tradition, only the learning media has been developed as needed.

Another research shows that the superiority of the learning system in Islamic Boarding Schools is the inculcation of religious values. Based on the perspective of pedagogy, this superiority is formulated in repetition learning tradition, such as memorizing and drilling. This learning system is an extraordinary strength even frightening for the West, especially if this benefits system is used in mathematics and science. Unfortunately, these two subjects are not seeing by Islamic Boarding Schools. The excellence of a learning system in Islamic boarding schools can be seen from four factors, i.e.learning material with its Facilities, Learning Actors, Learning Process and Learning Outcomes [2]. The research is library research which compares the advantages and disadvantages of learning systems in traditional and modern Islamic boarding schools. Salaf pesantren with characteristics of traditional learning did not necessarily change into modern learning because the traditional system also has many advantages.

The traditional Islamic boarding school system in the modern era is still needed because it is related to modern life or present life with technology that has become a necessity. Therefore, this synergistic relationship between two different systems (traditional systems and modern systems) will be able to provide the fulfillment of the spiritual needs of human beings [3]. The study concluded that the traditional learning system must remain preserved, even though modern systems have developed. The traditional system will be a reference in the development of modern education which is characterized by the development of technology. From these three studies, it can be seen that the Salaf pesantren still exists with traditional learning. This happened also at Pondok Pesantren Langitan, Widang, Tuban.

Langitan Islamic boarding school, Widang, Tuban is a salaf-based boarding school with the learning of the yellow book. Langitan Islamic boarding school was established by KH Muhammad Nur in 1852, in Mandungan Hamlet, Widang Village, Widang District, Tuban Regency, East Java Province. The learning system at this Islamic boarding school is still based on salaf tradition by studying the classical book. To improve the learning process, this pesantren seeks to adapt itself to social demands in today's digital era.

In this era, everyone is able to access various information in the network (online). Any information is available in cyberspace that makes it easy for anyone to get unlimited access to space and time. Every person, especially those who were born as digital natives, has a tendency for searching for information via the internet. They prefer to use the features of smartphones or other technological devices to surf in cyberspace either to find entertainment or to meet primary needs.

The background of Langitan Islamic boarding school has major challenges in developing its learning system. Langitan Islamic boarding school wants to develop a learning system through digital-based learning and without eliminating the classical learning system that has become a major tradition of the pesantren. According to the guidelines of the Langitan Islamic boarding school, al-Muhafadhotu 'ala qodim al-sholih wa al-Ahdu bi al-Jadid al-Ashlah.

This study attempts to complete previous studies by analyzing the continuity of classical and modern learning systems at Pondok Pesantren Langitan, Widang, Tuban. This study focused on classical and modern learning systems in that pesantren. This study will discuss a 
number of things, first, the classical learning system at Salaf Widang Tuban Islamic Boarding School, second, the modern learning system in the digital era, and third, the continuity of classical and modern learning systems in the Langitan Islamic Boarding School, Widang, Tuban.

\section{Method}

This research uses a case study approach which includes a study of a case in real life that is the learning system at the boarding school in Langitan, Widang, Tuban. In this study, classical and modern learning systems were examined which focused on the methods and media used in learning at the Langitan Islamic Boarding School, Widang, Tuban. The source of data in the study is the subject of where the data was obtained. Research subjects have the same position as researchers [4]. The research subjects in this study are kiai, bu nyai, ustaż/ ustażah, and santri. The scholars who were used as data sources in this study amounted to kiai, ustadz, and students amounted to 10 .

\section{Result and Discussion}

\section{Learning System In Salaf Islamic Boarding School}

The word Pondok (room, hut, small house) is used in Indonesian as "simplicity of the building". Pondok can also be taken from the Arabic word fund means a bedroom, guesthouse or simple hotel[5]. While "pesantren" according to the Indonesian Dictionary is a place for students or students to recite[6]. Pesantren in language comes from the word santri which gets the prefix and suffix, which means a place where the santri live in studying [7]. While etymologically, there are various opinions put forward by experts relating to the notion of "santri", including those expressed by Clifford Geertz [8], Abu Hamid [9], and Nurcholish Madjid [10]. ${ }^{1}$ It can be understood that a santri is someone who understands the religious sciences and applied into social behavior. So, the Islamic boarding school is a simple place where santri learns, especially religious knowledge, which will create their moral behavior and provide them with skills needed in the future.

The Government Regulation of Republic Indonesia Number 55 the Year 2007 Regarding Religious Education and Religious Education Article 26 Paragraph 1 explains the purpose of education in pesantren:

Islamic boarding schools organize education with the aim of instilling faith and piety in Allah SWT, noble morals, and pesantren traditions to develop the ability, knowledge and skills of students to become experts in Islamic religion (mutafaqqih fiddin) and/or to be Muslim who has the skills/expertise for creating an Islamic life in the community[11].

The education system in pesantren held every day. Santri is in the same area as the kiai and the teacher. Therefore, the relationship between students-teacher-kiai in the learning process exists intensively. This learning system brings many advantages [12]. First, caregivers conduct intensive monitoring of the intellectual and personal development of students. Second, there is a learning process with a high frequency, so that can increase the student's knowledge. Third, there is integration between the learning process and the daily life of students. Fourth, 
there is a process of habituation due to interactions during times, both with fellow students, with the cleric and also the kiai [13].

The conventional learning system and methodology adopted by pesantren generally use the methods of sorogan [14], wetonan [10], bandongan [15], halaqoh [16], and memorizing [16]. In contrast to the pesantren learning system after the New Order era, there are pesantren that held education such as formal education and teaching methods are no longer only by sorogan, wetonan, bandongan, halaqoh, and memorizing. Mustajab revealed that since al-Ottoman Islamic Boarding School applied the formal education system, the learning methods at the Islamic boarding school also increasingly develop with a variety of using lecture, experimentation, rote learning, discussion, and without eliminating previous methods such as classical book learning [17]. It figures out that the education system in pesantren has changed from the previous system, namely the traditional system, into a combined system of traditional and modern.

In the era of traditional Islamic education, teachers become central figures in learning activities. It is the main source of knowledge in the class and also becomes the only one. But in the context of modern Islamic education, this is no longer valid. Today, the role of teachers has changed into a facilitator for students. Learning is no longer centered on the teacher (teacher-centered), but more centered on students (student-centered).

The modernization of education which influenced pesantren education system was introduced by the Dutch colonial government. In the 19th century, Dutch colonialism allowed indigenous people to get an education. This program was carried out by the Dutch colonials by establishing volkschoolen, community schools, or village schools (nagari) with a three-year study period. Not only influenced by the Dutch, but a greater challenge to respond outside influences is also coming from Muslim modernists. Since the beginning of the 20th century, modernists have an argument that a reform of the Islamic education system is needed to respond to the advent of colonialism and Christian expansion. With this background in mind, two forms of modern Islamic educational institutions emerged: First, the Dutch public school model was given the content of Islamic teaching. Secondly, the madrasa that adopts the substance and methodology of modern Dutch education in a modern way [18].

Mujamil Qomar emphasized that the education system developed by pesantren in many ways is the result of an educational adaptation pattern that had existed in the previous HinduBuddhist community. This is not being a problem if the adaptation is only in the realm of methodology and not in the content of religious teachings. This strategy can serve to maintain the continuity of the develop tradition in society, keep in mind that the approach in da'wah Islamic society is adaptive-selective [12]. This strategy strengthens that pesantren education is referred to the Indonesian product of education system. Such a system by Nurcholish Madjid is called Indonesian genuine education [10].

The learning system in Islamic boarding schools did not only focus on making students intellectually smart. However, more than that, the effect of learning is reflected in the attitude of discipline, simplicity, independence, and other Islamic obligations [19]. This is what distinguishes education in Islamic boarding schools with formal education in general.

\section{Learning Systems in the Digital Era}

The digital era is a condition where everyone can access various information in the (online)network. Various information in this era is available in cyberspace which makes it easy for anyone to access without limits on space and time. The world became no barrier at all after the discovery of the digital system. Every person, especially those who are born as digital 
natives,has a tendency to search for information via the internet. They prefer to use the features of smartphones or other technological devices to surf in cyberspace either to find entertainment or to meet primary needs.

The great opportunities offered in this era, especially for the development and progress of the Islamic education world include the opening of information for the public to access educational information and programs, everybody can get articles freely without any requirements at all that can be accessed at various site addresses, opportunities to take part optimally in various fields, the opening of opportunities for increasing cooperation with various cross-agencies, and since the implementation of online-based learning, students can easily learn even to long-distance or not face to face [20].

The development of technology has given a new role for teachers. To develop computeraided learning models, teachers must work closely with experts in programming computerbased learning. This requires in-depth knowledge of the subject matter, the learning process, and understanding the development of students[21].

The development of technology, especially information technology, changes the perspective, the way of work, as well as the implementation in learning. This is marked by the emergence of new terms such as e-books, e-learning, and cyber universities. This is very different from traditional learning concepts, for example, someone who uses correspondence to deliver messages. At this time, someone just sent an email, Facebook, or Whatsapp and other features to send a message. The online interactions are not limited to passive material (letters), but also interactive material through correspondence (email/chat), video, orteleconferencing[22].

In higher education, the lecturer's efforts to set subjects into the digital world need special attention. State Islamic University Walisongo Semarang proposes with the existing courses to answer the challenges of the digital era. For example, the subject "Pengantar Ilmu Dakwah" (Introduction to Da'wah) explains not only the theories of da'wah, but also how to preach through multimedia. The da'wah textual theories can be implemented in contextual, so the theories of da'wah can be accepted by the public[23]. ${ }^{2}$ In addition to these efforts, it can also be through digitizing the material, so students and teachers can access the material data. The digitization process must be managed well and in collaboration with digital users who are experts in their fields[24]. ${ }^{3}$

For the community, the digital era and the development of information and communication media provide opportunities in the form of dissemination of learning opportunities and expansion of learning areas for all levels of society. Communities can get learning opportunities from other more advanced communities. Based on the perspective of learning, in addition to providing opportunities for expanding opportunities and expanding learning areas, the digital era also brings the complex challenges in various fields of life, particularly in the field of education.

One solution for children's education in the digital era is the parenting immune self-model. Through the parenting immune model and the compassion and self-awareness approach, children have a filter and immunity when they are not around their parents. Parents should instill a selective value of self in children for example about which information and access to news are good and suitable for the child's self [25].

Continuity of Classical and Modern Learning Systems at Salaf Islamic Boarding School, Langitan, Widang, Tuban 
Langitan Islamic Boarding School is one of the oldest institutions of Islamic education in Indonesia. It was established long before Indonesian independence, which was precisely in 1852, in Mandungan Hamlet, Widang Village, Widang District, Tuban Regency, East Java Province. The Langitan Islamic Boarding School Complex is located in the north of Bengawan Solo with a large of area approximately 7 hectares, approximately 7 meters above sea level. The location of the cottage is about 400 meters south of Widang sub-district or approximately 30 kilometers south of Tuban City, which also borders with Babat Village, Babat District, Lamongan Regency and only separated by a bridge that crosses Bengawan Solo[26].

Langitan Islamic boarding school havetwo learning systems, i.e. classical and ma'hadiyah. First, the classical system or called Madrasiyah System. The meaning of Madrasiyah, in this case, is madrasa diniyah (ie learning system that emphasizes religious sciences and Arabic) [27]. The curriculum taught is based on classical books with branches of knowledge. In certain lessons students are required to memorize several books, including Alala, Ro'sun Sirah, Aqidatul Awam, Hidayatussibyan, Tashrif al-Istilakhi, and Lughowi, Qowaidul I'ilal, Matan al-Jurumiyah, Tuhfathul Athfal, Arba'in an -Nawawi, 'I Rithi, Maqshud, Idatul Farid, Alfiyah ibn Malik, Jawahirul Maknun, Sulamul Munawaroq, and Qawaidul Fiqhiyyah. The learning process held on the class, no longer only uses the bandongan or wetonan method, but has been provided with using of projectors and LCD. This is one of Langitan Islamic Boarding School's efforts for adjusting technological developments.

As support and complement to activities that are in madrasah and to involve all students, the Langitan Islamic Boarding School also applies extra-curricular activities which include: musyawaroh or munadzoroh (discussion). To expand its da'wah, the madrasah system has a da'wah institution namely Harokah Magazine. This magazine is the creation of santri alFalahiyah which contains discourses, profiles of figures, the Muslim world, wirids, quizzes, and essays. Besides available in printed form, this magazine can also be downloaded Emagazine version.

Fig. 1. Facebook of Majalah Harakah http://facebook.com/MajalahHarakah

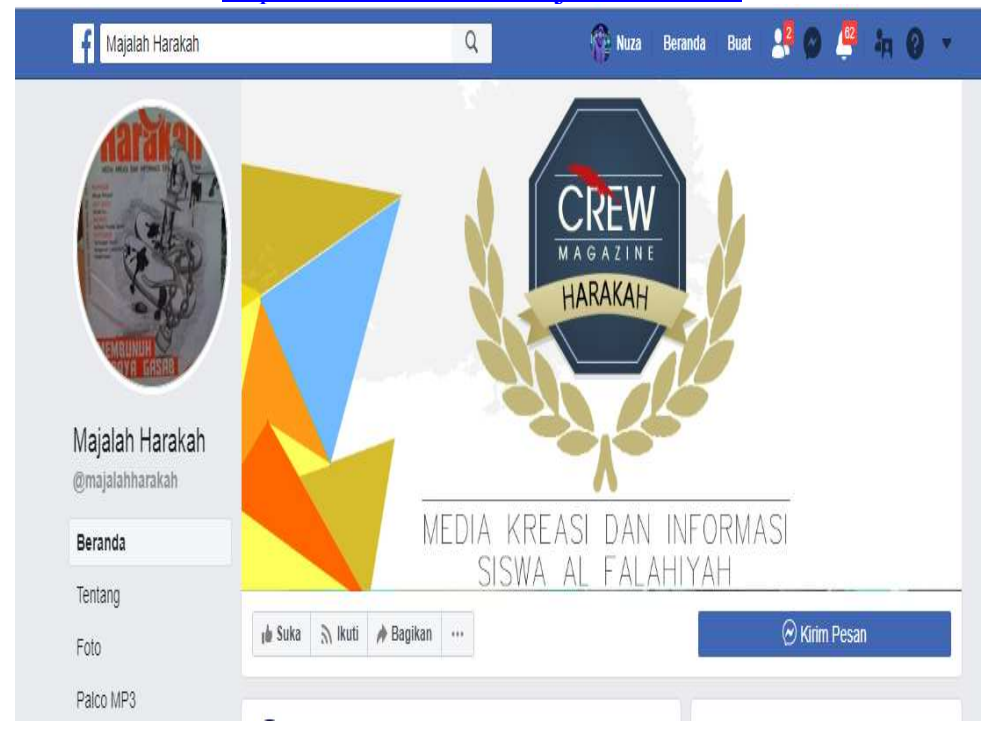


Second, the non-classical system or called withma'hadiyah system. The methods in this study are sorogan, wetonan, and bandongan. The implementation of ma'hadiyah system is divided into two groups, namely general and takhassus. The general system, which is the ma'hadiyah program,which is held every day except Tuesday and Friday. The schedule of book and time are adjusted to the schedule which has been made. This learning is lead by the direct scholars (masyayikh), only if the scholars is absent, replaced by ustadz. takhassus system, which is a special education program for students after Aliyah and other students who experts in basic science such as Nahwu, Shorof, Aqidah, Sharia. This program is more popularly called Musyawirin which is managed directly by Majlis Masyayekh. The implementation is every day except Tuesday and Friday, the material being taught is fiqh fan like Fathul Muin, Mahalli, and Hadith fans such as Jawahirul Bukhori and Riyadus Sholikhin.

The learning process in Pondok Pesantren Langitan, not only limited to students but can also be followed by alumni and the wider community. Learning classical books for the alumni is held every Sunday among the books studied, i.e. Shohih Bukhori and Ihya' Ulumuddin.

In addition to being able to study directly with the community, the study of books carried out can also be followed by the wider community through Langitan $T V$ and life-streaming Youtube every evening. This is the development of classical media towards modern media in society. Here the role of the media is very important in studying classical books in the wider community. Langitan Islamic Boarding School continues to try to adapt to the conditions of the community outside without reducing the embedded tradition in the Boarding School.

Fig. 2. Langitan TV

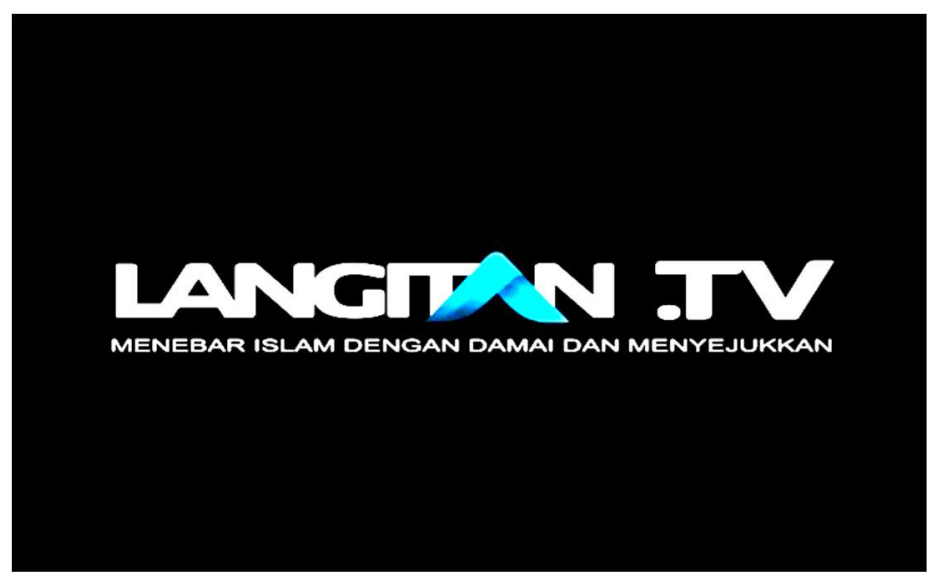

The Langitan boarding school emphasizes not only the mission of education but also its mission ofda'wah. Even this second mission is more prominent than the first[12]. The Langitan boarding school attempts to preach to the students and the wider community by publishing a magazine called Kaki Langit. This magazine was published in printed form, but now it can be downloaded online. This magazine contains contemporary issues, including fiqh lanterns, hadiths, wisdom, Islamic history, carawala corner pesantren, and other Islamic insights. 
Fig. 3. Langitan Magazine Online[28]

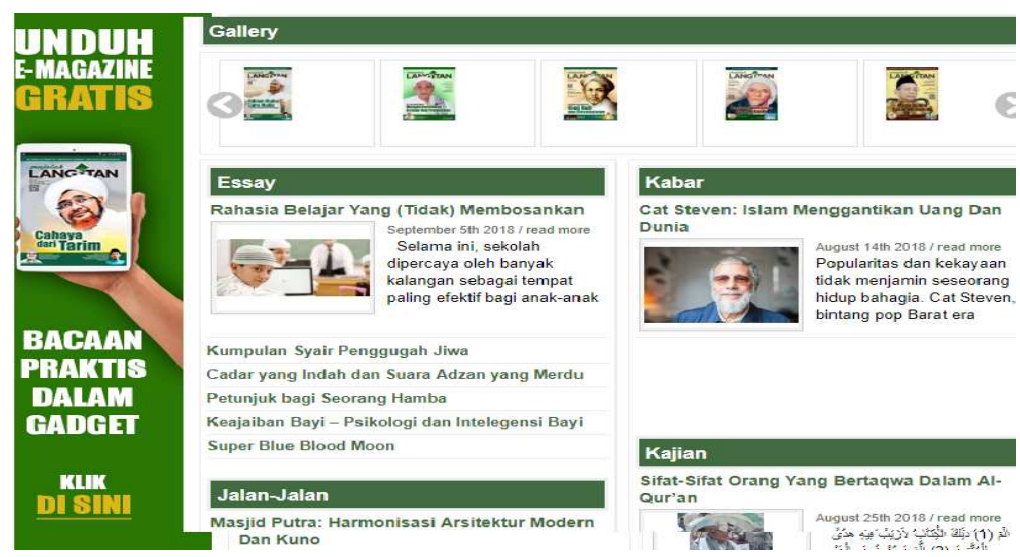

We can also download the Langitan video application through the Play Store that includes studies like tausiyah, FAQs on fiqh, and daily issues, as well as prayer.

Fig. 3. Langitan Radio

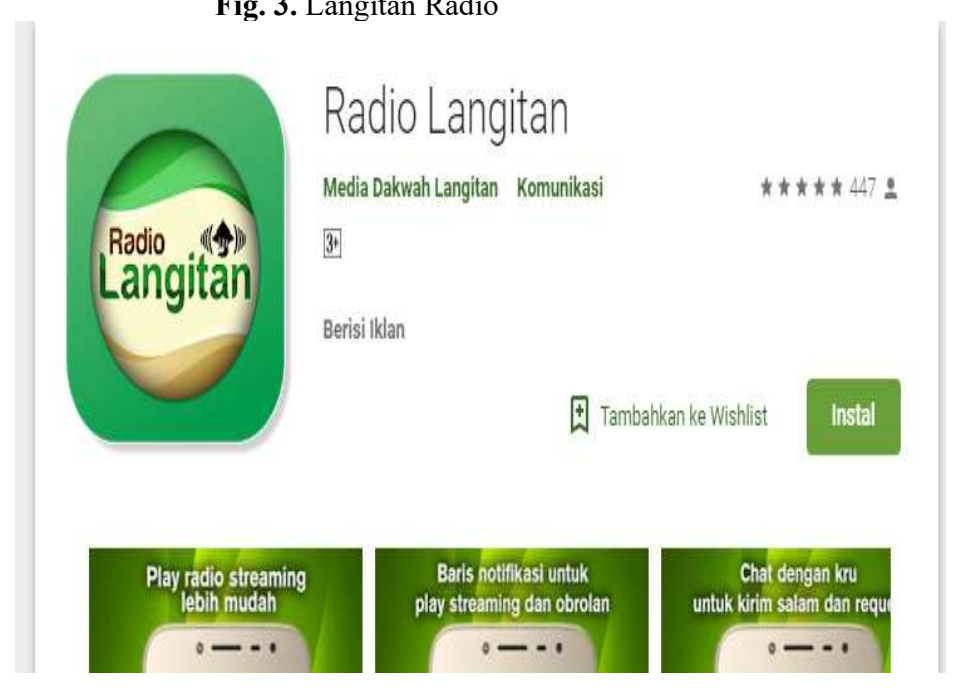

The formation of an interactive learning system is not limited to one location. Langitan boarding school maintains its salaf tradition in Pondok Pesantren. However, for learning that oriented to the outside community, this pesantren uses online media. Although based on salaf system, the Langitan pesantren does not close itself with rapid technological development. Besides those media mentioned above, other social media are used, such as Instagram: MenaraLangitan, Facebook: MajaahLangitan. The Langitan Islamic boarding school has also received a memorandum of understanding between the Langitan da'wah media with NU online and Nutizen (both of are the official PBNU Jakarta media), regardless of having santri Langitan Informatics Community (KAFI). 


\section{Conclusion}

The learning system in an Islamic boarding school has many changes since its establishment. These all due to internal and external factors of Islamic boarding school. Langitan Islamic boarding school does not only maintain their salaf learning system but also adapt to the development of the digital era. To maintain their salaf tradition, Langitan Islamic boarding schools still maintain the traditional system such as sorogan, wetonan, and bandongan in the learning of classical books. In the madrasiyah learning at the class, this boarding school has provided with LCD although not all of the classes.

The learning ma'hadiyah system of Islamic boarding school is developing a digital system for da'wah to wide society. in this system, the goal of Islamic boarding school is not only to study classical books with their students but also learning with a wide society through digital media, such as Langitan TV, Instagram, Facebook, Langitan online magazine, Langitan Radio. The learning system still uses classical methods like wetonan, bandongan and sorogan. The main point learning system uses a digital system in the way of da'wah to the wide society outside the Islamic boarding school area.

\section{References}

[1] Kadi, "Kesinambungan dan Perubahan Tradisi Salaf dalam Sistem Pendidikan Pondok Pesantren Lirboyo Kediri,” J. Islam., 2017.

[2] Fachrurazi, "Pembaharuan Sistem Pembelajaran Pondok Pesantren (Tradisional Versus Modern)," J. Turats, 2016.

[3] S. A'dhom, "Sistem Pendidikan Pesantren Trdisioal dalam Era Modern," J. Pusaka, 2015.

[4] M. Yusuf, Metode Penelitian: Kuantitaif, Kualitatif \& Penelitian Gabungan. Jakarta: KENCANA, 2014.

[5] M. Ziemik, Pesantren Islamische Bildung in Sozialen Wandel, terj. Butche B. Soendjojo. Jakarta: P3M, 1986.

[6] "Kamus Besar Bahasa Indonesia.".

[7] A. Anwar, Pembaruan Pendidikan di Pesantren Lirboyo, Kediri. Jakarta: Pustaka Pelajar, 2011.

[8] C. Geertz, The Religion of Java terj. ASwab Mahasin dan Bur Suwanto, Depok, Komunitas Jaya. 2014.

[9] Abu Hamid, Sistem Pendidikan Madrasah dan Pesantren di Sulawesi Selatan, dalam, Taufik Abduilah (Ed.), Agama dan Perubahan Sosial. Jakarta: Rajawali Press, 1983.

[10] N. Madjid, Bilik-bilik Pesantren: Sebuah Potret Pejalanan. Jakarta: Paramadina, 1997. 
[11] "The regulation of Republic indonesia number 552007 about religion education and religious education pasal 26 ayat $1 . "$.

[12] M. Qomar, Pesantren dari Transformasi Metodologi menuju Demokratisasi Institusi. Jakarta: Erlangga, 2007.

[13] L. R. dan H. Haika, "Modal Sosial Pendidikan Pondok Pesantren," J. Harmon. Sos., vol. 1,2014

[14] Muhtarom, Reproduksi Ulama di Era Global. Yogyakarta: Pustaka Pelajar, 2005.

[15] Binti Maunah, Tradisi Intelektual Santri. Yogyakarta: TERAS, 2009.

[16] A. dkk Haedari, Masa Depan Pesantren: Dalam Tantangan Modernitas dan Tantangan Komplesitas Global. Jakarta: IRD press, 2004.

[17] Mustajab, Masa Depan Pesantren: Telaah atas Model Kepemimpinan dan Manajemen Pesantren Sala. Yogyakarta: LKis, 2015.

[18] A. Azra, Pendidikan Islam Tradisi dan Modernisasi di Tengah Tantangan Milenium III. Jakarta: KENCANA, 2012.

[19] K. A. Steenbrink, Pesantren Madrasah Sekolah: Pendidikan Islam dalam Kurun Modern. Jakarta: LP3ES, 1994.

[20] Nuryadin, "Strategi Pendidikan Islam Di Era Digital," J. Fitrah, vol. 03, no. 1, 2017.

[21] S. Anshori, "Strategi Pembelajaran Di Era Digital (Tantangan Profesionalisme Guru Di Era Digital)," in Prosiding Temu Ilmiah Nasional Guru (Ting) Viii, 2016.

[22] “ Hardoyono, Fajar, "Strategi Pembelajaran Era Digital: Usulan Skenario dalam Menyambut Transformasi STAIN Purwokerto sebagai Salah Satu PTAI yang Mengembangkan Cyber Kampus," J. Pemikir. Altern. Pendidik., vol. 12, no. 1, 2017.

[23] R. Aji, "DIGITALISASI, ERA TANTANGAN MEDIA (Analisis Kritis Kesiapan Fakultas Dakwah Dan Komunikasi Menyongsong Era Digital)," Islam. Commun. J., vol. 01 , no. $01,2016$.

[24] S. Alfinnas, "Arah Baru Pendidikan Islam di Era Digital," J. Pendidik. dan Manaj. Islam, vol. 7, no. 1, 2018.

[25] W. Setiawan, "Era Digital dan Tantangannya," Semin. Nas. Pendidik., 2017.

[26] Tim Redaksi, History Lantany dalam SAHEEBA. Tanpa Penerbit, 2010.

[27] D. Tim Penulis, "Pondok Pesantren dan Madrasah Diniyah, 15."

[28] “http://pondok.pesantren.or.id/2012/12/pondok-pesatren-langitan.html.”. 


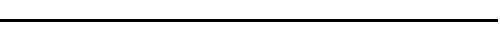

